\title{
Editorial
}

\section{My bucket list}

\section{Prof Keshav Das Joshi}

Burns, Plastic and Reconstructive Surgery

Email: keshavdasjoshi@gmail.com

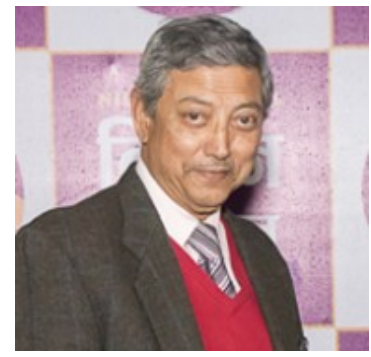

Son of Ram Das Joshi , Prof Keshav Das Joshi was born at Kathmandu. He completed MBBS on 1968 from Trivandrum Kerela, residency (1970 to 1974) in MS (General Surgery) on 1974 from AIIMS, New Delhi. He served as a registrar on 1975 at Maulana Azad Medical College and training in Clinical Oncology in Tokyo at the National Cancer Hospital) on 1983. He had his training in Plastic Surgery in U.K. 1987 and various periods of training and Observation in Burn \& Plastic Surgery in Canada, Belgium, France, Singapore and Switzerland.

Since 2032 he has worked as a general surgeon in Butwal Hospital, Lumbini Anchal, Bheri Anchal Hospital followed by six years in Gandaki Zonal Hospital a total of 10 years. The history of Burns and Plastic surgery services in Nepal was started in Bir hospital. The separate Burns and Plastic surgery unit was established in the year 1998 AD. Dr Keshav Das Joshi, senior consultant plastic surgeon, proposed it. In his endeavor the first organized Burn Unit was established in 2000 A.D. For his contribution to the society he has been felicitated by the government by 'Gorkha Dakshin Bahu' Third, 'Trishaktipatta' Third, 'Birendra Aishworya Sewa Padak' etc to name a few.

He served as the president of Society of Surgeon of Nepal for the period 1999 - 2002. He served as the editor of souvenir of the third International Surgical Conference of SSN on 1994. He had a major role in the establishment of the Journal of Society of Surgeons of Nepal (JSSN). He served as the chief editor for the period 1998, 1999.

"I have seen the moment of my greatness flicker And I have seen the eternal Footman hold my coat and snicker, And in short, I was afraid."

\section{T. S. Eliot}

I turned 72 last December 2016. And I realized how lucky I have been. But, slowly I have come to think of my mortality. How much longer will I live? I have lived longer than my two eldest brothers and my cousin brothers. My father lived to the age of 73 and died from cancer stomach. On the other hand my uncle lived to 93 pretty much in control of his faculties right to the end. Cancer runs in the family, cancer of liver, pancreas, lungs, uterus, breast; leukemias, lymphomas, you name them. Why, how did they happen in my family? No doubt, over the years diagnosis have got better and also management of the diseases. Of course, the cost of treatment has risen very sharply and some of the drugs are not available in Nepal. But, even here, if the disease is caught early the survivals have improved. But, one does need a little bit of luck to get properly and correctly diagnosed and treated, perhaps by an experienced physician or surgeon, who can also refer the patient to a proper colleague or hospital.

And amongst my medical colleagues and friends so many have passed away, many to prostatic cancer. And I wonder how did these friends manage and cope with their diseases knowing the implications and prognosis. Interesting? I would not know until someone mentioned that 'phalana phalana' doctor died and you remember him and say 'RIP friend'.

As I have got older my contacts with my friends have become tenuous. I suppose they get involved with their petty affairs, their children, grandchildren and all their social commitments. One was a close friend has now become distant. A few of his trekking friends died from various ailments so he has lost interest in keeping touch. A few have become ill and are busy getting treated. One of my good friend with whom I grew up was suffering from liver cancer which had been removed but had recurrences of the disease for which he went to Delhi for TARE and 
TACE which are very expensive. He is also a doctor and his temperament has always been stubborn and cool. I am sure he is aware about the nature of his disease and that the prognosis is not good; yet, he struggled on bravely with equanimity. He died from complications while closing a colostomy, in a famous hospital in New Delhi. How and Why? Never knew why it happened. Shocking!

Last month, a senior engineer friend died; I had seen him on and off. Unfortunately, he was diagnosed with oesophageal cancer when the disease was advanced. He had ignored the symptoms earlier. He went to Delhi and had expensive chemotherapy a few months ago. When I met him a couple of days before he died I asked him how he was. He answered not very good. His relations told me he did not make too much fuss till the end. He was brave.

Paul Kalanthi, a brilliant neurosurgeon in Stanford died from stage IV lung cancer and chronicles his life in " When Breath Becomes Air". It is a very touching, moving memoir. He died while writing this best seller book. His wife completed the book. He writes, "Coming to face with my own mortality, in a sense, had changed nothing and everything". He further quotes Samuel Beckett "I can't go on. I'll go on". He fought till the end and availed the state of art care that America could offer. It was painful in the end.

In the last one year, I have come into contact with relatives and friends with diagnosis of various types of cancers. My eldest sister, in her early eighties, had a large opaque shadow in the left lung that looked suspicious. After some investigations and consultations the diagnosis was inconclusive. Her appetite was good and she had no pain yet. I had suggested a diagnostic FNAC. The treatment, of course, would change with radiation or chemotherapy and prolong her life for better or worse. I was asked to mind my business! She had earlier suffered enough with two knee joint replacements; two fractures femurs, one probably a pathological fracture. Bone biopsy from fracture site was not helpful. She passed away without fuss from lung complications. Chemotherapy might have prolonged her life a few more months. Our oncologists are ever ready to try so many new drugs.

Another friend died within six months peacefully from pancreatic cancer not knowing much about the disease. How common is pancreatic cancer? A relative living nearby also died from complication post operatively after resection of the growth in the pancreas. Only the treating doctors knew the complication that occurred. It again happened in a famous hospital in Delhi.

So am I ready? In many, many ways no, I am not ready.
I am not ready to die. Do we start to think about it when the disease strikes us? Something incurable? Talking about death, planning for death. Making some sort of a will, so that if we go suddenly our children will know what we have bequeathed to them. It is not the practice in Nepal to write wills but one should. Especially in these uncertain times with earthquakes and other natural calamities occurring on and off, we should give a serious thought to it.

And what should I do in the remaining time of my life? Here are some of my Bucket lists.

1. Love my close family. Spend quality time with them. See the children grow.

2. Travel. See the world. I would love to go to Europe where so much history happened.

3. Read, which I like to do. Buy books when I can. Don't enjoy Kindle so much. The enjoyment is in going into a bookstore and spending leisurely time in the shop browsing.

4. Print my 'Newari cook book'. Rough part is ready. I have to type it with the correct weight of the masalas. Then print it. Like Chinese food we Newars have so many exotic preparations. It is not only 'samay bajee, chata mari', etc. There is lot more to it.

5. Exercise. I walk a lot; four to five kilometers every day, even when outside the country. A recent trip to Japan added many kilos; eating lot of sashimis, sushis etc. It was wonderful travelling with my two grandsons and daughter. Japan with its old culture, cleanliness is another world. Kyoto is beautiful with their many temples so clean and so well kept.

6. Watch the movies I love and see the sports I enjoy. I would like to see concerts and opera although the tickets are very costly. However, opera is not available in my country.

7. Be more tolerant and understanding of others. Do not give 'dukha' to others. Try to be good and helpful.

8. Hope to see the country get out of this morass, misery and depression.

9. To see a charismatic leader lead the country. Saw the P. M. of Bhutan talk at a TED show and what an inspiring performance. A true leader.

10. Drink the 'Melamchi' water before I die. Already 25 years in the making. They say it will come by 2017 . Amen. 
11. See ' bijule' 24 hours a day. Do not want to hear how rich we are in water resource, ad nauseum.

12. Even now be a better husband and father, grandfather, even though the children are scattered around the world.

13. I do not want to be ventilated. End my hours with a good dose of opiates. Avoid the unneccesary chemotherapy, antibiotics etc .

14. I want to be cremated in the electric crematorium and save scarce wood. I do not think Vedic cremation will make any difference as to where I will go in the end.

The title of this not so very happy article was popularized by a Hollywood movie starring two wonderful, seasoned veteran actors Morgan Freeman and Jack Nicholson. The movie is very enjoyable and I recommend it.

Philip Roth wrote in Everyman "Old age is not a battle, old age is a massacre." We doctors see so much of death that we do not think of our own mortality. Should we not listen to the very sick who are critically ill and listen to their desires in the end and what he hopes and would like done. Spend more time for this with the patient. Hospice services are yet not freely available, where the end can be made with dignity and peacefully. The staffs there will talk, spend time and give the right choices and to give courage. Courage is strength in the face of knowledge of what is to be feared or hoped. In aging and sickness we need it; to confront our mortality and to act on the truth we find.

I end this article by quoting some lovely passages I have liked.

Dylan Thomas:

“ Do not go gentle into that good night,

Old age should burn and rage at close of day,

Rage, rage against the dying of the light."

Albert Camus:

"Great courage is to gaze as squarely at the light as at death."

Ecclesiastes:

"A time to love and a time to die and when my skein runs out I hope to face the end calmly and in my own way." 